\title{
Duma i uprzedzenie jak historia romantyczna. O adaptacji powieści Jane Austen w reżyserii Joe Wrighta
}

\begin{abstract}
Pilawska Roksana, Duma i uprzedzenie jak historia romantyczna. O adaptacji powieści Jane Austen w reżyserii Joe Wrighta [Dirty (un)Romantic story. An Analysis of Aesthetic Aspects in the Film Adaptation of Pride and Prejudice Directed by Joe Wright]. „Przestrzenie Teorii” 32. Poznań 2019, Adam Mickiewicz University Press, pp. 417-431. ISSN 1644-6763. DOI 10.14746/pt.2019.32.23.

The aim of my study is to attempt a comparative analysis of the two most famous film adaptations of the bestselling novel by Jane Austen, Pride and Prejudice. As research material, I chose the mini-series produced by the BBC in 1995, which was part of the then popular trend of heritage films (heritage cinema) and the feature film from 2005, directed by Joe Wright, which, in the opinion of film experts, was a completely new form of audiovisual presentation of Austen's work. In the article, I focus only on interpreting the aesthetic aspects of both productions, which would indicate similarities and differences, thus showing numerous shifts of emphasis in the aesthetic layer of the newer version.
\end{abstract}

KEYWORDS: Pride and Prejudice, Jane Austen, Joe Wright, heritage films, film adaptations, aesthetic aspects

\section{Wstęp: o fenomenie Jane Austen}

Jane Austen - żyjąca na przełomie XVIII i XIX wieku pisarka, tworząca powieści o romansach i drobnych intrygach prowincjonalnej szlachty. Mimo ich pozornej prostoty od niemal dwustu lat owa autorka ma liczne grono wiernych i oddanych czytelników w każdym kolejnym pokoleniu. W celu zrozumienia tego niewattpliwego fenomenu kultury popularnej można powołać się na dziennik szkockiego poety Waltera Scotta, w którym autor pisząc o twórczości Austen, stwierdził, że jej talent - opisywania uczuć i przeżyć bohaterów w codziennym życiu - był najwspanialszym darem, z jakim do tej pory się spotkał1 ${ }^{1}$ Przeglądając materiały źródłowe o twórczości pisarki,

${ }^{1}$ J. Stillinger, M.H. Abrams, The Romantic Period, [w:] The Norton Anthology of English Literature, vol. 2, red. M.H. Abrams, New York, London 1995, s. 20, za: A. Wróblewska, Wspótczesne adaptacje powieści Jane Austen. „Lizzie Bennet Daries” jako narracja transmedialna, „Biblioteka Postscriptum Polonistycznego” 2015, nr 5, s. 77-91. 
znalazłam fragment artykułu, w którym autorka Dumy $i$ uprzedzenia jest wręcz określana mianem „najznamienitszej klasycznej brytyjskiej pisarki, której twórczość odgrywa w kulturze popularnej rolę tak wielka jak dzieła Williama Szekspira"2. Ten pogląd podziela także znakomity amerykański literaturoznawca Harold Bloom ${ }^{3}$. To śmiałe stwierdzenie jest również odzwierciedlone w opinii filmoznawców, według których powieści Jane Austen dostarczały treści (w tym samym wymiarze co twórczość Szekspira) do charakterystycznych adaptacji filmowych określanych mianem heritage films - kina dziedzictwa.

W latach dziewięćdziesiątych ubiegłego wieku filmy powstałe na bazie klasycznych powieści wyraźnie odnosiły się do brytyjskiej tradycji i historii, przedstawiając ponadczasowe dzieła autorów w konserwatywny sposób za pośrednictwem pieczołowicie odtwarzanych kostiumów, rekwizytów i wnętrz z epoki, zdjęć angielskiej wsi i dworu, konwencjonalnej pracy kamery, a także charakterystycznej formy estetyzacji tworzącej wrażenie teatralności. Powyżej opisana „sztuczność” i „przeestetyzowanie” widoczne były między innymi w znanej adaptacji Dumy i uprzedzenia (1995, BBC) ${ }^{4}$. Za sukcesem serialu stały nie tylko jego walory artystyczne, za które produkcja została nagrodzona Emmy. Istotne było także, że adaptacja ta stanowiła idealną odpowiedź na aktualna sytuację społeczno-polityczną. Według Madaleine Dobie od lat osiemdziesiątych filmy kostiumowe łagodziły tarcia społeczne wywołane polityką poprzez odwoływanie się do tradycji, a z kolei w latach dziewięćdziesiątych stały się płaszczyzną do poruszania kwestii związanych z feminizmem, kobiecością i płciowością. Teoretycy o poglądach konserwatywnych uważali natomiast, że produkcje stworzone w nurcie heritage films odpowiadały na tęsknotę za pięknem i porządkiem „dawnych czasów” widoczną we współczesnym społeczeństwie - promując tym samym tak zwany „romantyzm udomowiony”. Kino dziedzictwa ukazywało określona, uporządkowaną i przeestetyzowaną wizję przeszłości, wywołująca charakterystyczne poczucie nostalgii ${ }^{6}$. Wzrost popularności powieści pisarki oraz ich filmowych adaptacji spowodował, że od roku 1995

${ }^{2}$ O. Kowalska, Wspominajac wielkich: Nieśmiertelna Jane Austen, <http://niestatystyczny.pl/2017/01/14/wspominajac-wielkich-niesmiertelna-jane-austen/> [dostęp:16.01.2019].

${ }^{3}$ Por. jego uwagi o Jane Austen: H. Bloom, Zachodni kanon, przeł. B. Baran i M. Szczubiałka, Warszawa 2019; tegoż, Jak czytać i po co, przeł. A. Kunicka, Warszawa 2019.

${ }^{4}$ A. Urbanik-Kopeć, Czepek z kokarda $i$ ubłocona sukienka - estetyczne uniwersum filmowych adaptacji powieści Jane Austen, [w:] 50 twarzy popkultury, red. K. Olkusz, Kraków 2017, s. 402.

${ }^{5}$ Za: P. Włodek, Domniemany konserwatyzm heritage film, „Ekrany” 2012, nr 5/6, s. 57.

${ }^{6}$ M. Olszowska, Duma i uprzedzenie Jane Austen: historia Lizzy, [w:], Od Jane Austen do Iana McEwana. Adaptacje literatury brytyjskiej, red. A. Helman, B. Kazana, Warszawa 2011, s. 39. 
w kilkumiesięcznych odstępach pojawiała się na ekranach nowa produkcja filmowa nawiązująca do twórczości Jane Austen, a sam trend z czasem został określony mianem austenmanii, Jane-manii, Jane Adiction lub Jane Reaction ${ }^{7}$.

Tematyka austenmanii została szeroko omówiona w licznych tekstach autorstwa zarówno filmoznawców, kulturoznawców, jak i literaturoznawców. Interesujacym zagadnieniem stają się nowe adaptacje i retellingi (zwane też „recyklingiem” klasyki literackiej ${ }^{8}$ ) powstałe w ciagu ostatnich 10-15 lat, jak na przykład: Duma i uprzedzenie w wersji Bollywood (G. Chadha, 2004) lub Duma $i$ uprzedzenie i Zombie (B. Steers, 2016). Powyższe adaptacje korzystając z innej konwencji, równocześnie zmieniają fabułę, traktując oryginalną powieść jako źródło swobodnej inspiracji. Prawdopodobnie jedna z najbardziej znanych retellingowych adaptacji jest Dziennik Briget Jones, przedstawiająca tę konwencjonalną historię we współczesnych realiach (wybór Colina Firtha na odtwórcę roli Marka Darcy'ego nie był przypadkowy).

Chciałabym się tu skoncentrować wyłącznie na analizie pełnometrażowego filmu z 2005 roku w reżyserii Joe Wrighta. Adaptacja ta nie została przez publiczność przyjęta równie życzliwie, co serial wyprodukowany przez BBC dziesięć lat wcześniej. Jednak widoczne odejście twórców Dumy $i$ uprzedzenia od stylistyki heritage films sprawia, że film staje się interesujacym materiałem, na podstawie którego można zadać pytanie o charakter dokonanego tu stylistycznego przewrotu oraz przesunięcia akcentów $\mathrm{w}$ warstwie estetycznej. Po dokonaniu interpretacji zabiegów wizualnych wykorzystanych przez reżysera, chciałabym spróbować udzielić odpowiedzi na pytanie o ich znaczenie dla fabuły filmu w kontekście zawartych w powieści elementów romantycznych.

\section{Wichrowe Wzgórza i brązowe gęsi}

Jeśli za cechę wyróżniającą heritage films uzna się ich charakterystyczną warstwę wizualna przedstawiajacca „przeestetyzowane historyczne dramaty" pozornie odchodzi od tego rodzaju estetyki i podąża w kierunku realizmu, mroku, a nawet pewnego weryzmu nieukrywającego przed widzem tego, co w świecie przedstawionym „brudne” i „zabłocone”. Podczas wizyty w talk-show Grahama Nortona, Keira Knightley wyznała, że początkowo nie była

${ }^{7}$ A.M. Scholtz, From Fidelity to History: Film Adaptations as Cultural Events in the Twentieth Century, New York 2013, s. 123.

${ }^{8}$ A. Wróblewska, dz. cyt., s. 78.

${ }^{9}$ A.M. Scholtz, dz. cyt., s. 125. 
brana pod uwagę przez producentów przy obsadzie głównej roli ze względu na wyróżniającą urodę. Dopiero po spotkaniu z aktorka, Joe Wright stwierdził, że nie jest ona „aż tak ładna” i w związku z tym może zagrać Elizabeth Bennet ${ }^{10}$. Choć ta anegdota została przez aktorkę przywołana prawdopodobnie w celu rozbawienia widowni, to jednak doskonale ilustruje zwrot, jaki w owym czasie dokonał się w sposobie adaptowania dzieł Jane Austen.

Podczas przygotowań do realizacji filmu reżyser nie tylko szukał „nie za ładnych” aktorów, ale także „niezbyt ładnego” otoczenia i miejsc, w których mogłaby się rozgrywać jego akcja. Film otwiera obraz wschodu słońca na wzgórzu, w tle słychać muzykę wykonywaną przez światowej sławy pianistę Jeana-Yves'a Thibaudeta. Scena pozornie wydaje się wpisywać w estetyczną konwencję świata georgiańskiej obyczajowej powieści. Jednak samo wzgórze nie przypomina już klasycznego, sielskiego pejzażu XVIII-wiecznej Anglii przedstawionego we wcześniej wspomnianym serialu. Film opowiada o życiu codziennym angielskiej szlachty z początków XIX wieku, a zamglone i pogrążone w ciszy wrzosowisko bardziej pasuje do gotyckich powieści sióstr Brontë niż wcześniej wspomnianej wizji estetycznego klasycyzmu. W kolejnym ujęciu pojawia się postać Elizabeth, trzymającej w ręku powieść o miłości. Scenę - przypominająca obraz Caspara D. Friedricha Kobieta na tle zachodzqcego stońca - można interpretować na wiele sposobów. Zwracając większą uwagę na aspekt fabularny i psychologiczny, można przyjąć, że moment przejścia Elizabeth przez kładkę z ogrodu na podwórze symbolizuje jej wewnętrzne rozdarcie między romantyczną duszą marzącą o prawdziwej miłości a poczuciem obowiązku względem rodziny ${ }^{11}$. Analizując tę scenę $\mathrm{w}$ aspekcie estetycznym, można ją interpretować jako symboliczne zerwanie z wcześniej przedstawionymi mglistymi, romantycznymi pejzażami na rzecz realistycznych, rodzajowych obrazów z życia codziennego. Kamera podążająca za Lizzie, w następnych sekundach pokazuje: wywieszone na sznurkach pranie, przy którym krzątają się służące, biegające po podwórzu kury i psy myśliwskie, brudną sadzawkę z pluskającymi się w niej kaczkami i obdrapane ściany starego domostwa. Twórcy - dla utrzymania owej „estetyki brzydoty” - zachowali tak dużą dbałość o szczegóły, że nawet gęsi karmione przez parobka na tyłach domu nie są białe, lecz brązowe.

${ }^{10}$ BBC America, Keira Knightley Is Not Too Pretty For Movies - The Graham Norton Show on BBC America, YouTube.com 2014, <https://www.youtube.com/watch?v=FypcyrvpTp4> [dostęp: 20.05.2019].

${ }^{11}$ P. Skrodzka, Kulturowe uwarunkowania wyboru posiadłości wykorzystanych na planie Dumy i uprzedzenia, <www.janeausten.pl/317,groombridge-place-oraz-basildon-park-jako-przykład-wykorzystania-3> [dostęp: 20.05.2019]. Jest to część pracy magisterskiej Pauliny Skrodzkiej, która została opublikowana na tej stronie. Tytuł pracy to: Groombridge Place oraz Basildon Park jako przyktad wykorzystania angielskiej architektury wnętrz przy kreowaniu filmowej rzeczywistości $w$ dziele „Duma i uprzedzenie” $w$ reżyserii Joe Wrighta. 
Do odtworzenia posiadłości Longbourn reżyser wybrał XVIII-wieczny dwór Groombridge Place. Jest to budynek otoczony fosa, którego kształt nie zmienił się od ponad 300 lat. Charakterystyczny wygląd oraz położenie dworu nad wodą przywodzą na myśl zaklęty zamek, w którym pięć młodych dziewic oczekuje na wybawienie przez przystojnego i bogatego księcia - pokroju pana Darcy'ego. Długie ujęcie przedstawiające Longbourn po raz pierwszy zostało podzielone na dwie części. Na początku widz poznaje zabudowania gospodarcze i tyły posiadłości, a następnie frontalną część domu. Kolejna scena rozgrywająca się już wewnątrz dworu przedstawia młodsze córki państwa Bennetów (ubrane w wygniecione, proste sukienki), beztrosko biegające między pokojami. Płynne i swobodne przejścia kamery przez ściany i wystrój poszczególnych pomieszczeń dają wrażenie spontanicznej naturalności. Charakterystyczne ujęcia zza okien w zamyśle reżysera miały eksponować związek między sytuacjami na zewnątrz i wewnątrz domostwa ${ }^{12}$. Ta perspektywa sprawia także, że widz może mieć wrażenie ukradkowego podglądania momentów z codziennego życia rodziny - co zapewnia odbiorcy poczucie bliskości i możliwość utożsamienia $\mathrm{z}$ bohaterami.

Sekwencja wejścia Elizabeth do domu kończy się najazdem kamery na leżący na stole czepek z kokarda - charakterystyczne nakrycie głowy, w którym na ogół były przedstawianie bohaterki we wcześniejszych adaptacjach powieści Jane Austen. W filmie Wrighta żadna z pokazanych kobiet nie ma go na głowie - tym samym jest on kolejnym przedmiotem potęgujacym wrażenie rozgardiaszu panujacego $\mathrm{w}$ domu, podobnie jak kapelusz pozostawiony w salonie lub liczne kubki i ścierki. Powyżej opisaną scenę można więc interpretować jako symboliczne zerwanie $\mathrm{z}$ dotychczasowym przedstawianiem powieści pisarki w nurcie heritage films. Wcześniejsza uładzona „estetyzujaca estetyka” zostaje pozornie porzucona na rzecz rozgardiaszu i ogólnego nieładu niczym czepek jednej z sióstr Bennet ${ }^{13}$.

\section{Romantyczna sceneria w gotyckim wydaniu}

W filmowej adaptacji - pełnej szarości i brudnych błękitów - promienie słońca zostały w znacznej mierze zastapione mglistymi brzaskami, deszczem i pochmurnym niebem. Inne są też krajobrazy. Zamiast malowniczych pagórków zachęcających do popołudniowych spacerów pojawiła się majestatyczna scena przedstawiajacca główną bohaterkę w rozwianej przez wiatr sukni nad brzegiem klifu. Ta charakterystyczna i rozpoznawalna scena z podróży

\footnotetext{
${ }^{12} \mathrm{Na}$ podstawie wywiadu z Joe Wrightem zamieszczonym jako materiał dodatkowy do wersji filmu wydanej na DVD w 2006 roku.

${ }^{13}$ A. Urbanik-Kopeć, dz. cyt., s. 405.
} 
Elizabeth symbolizuje (dość konwencjonalnie) wewnętrzną przemianę bohaterki i rozkwit jej uczuć względem pana Darcy'ego. Romantyczności ujęciu dodaje także specjalnie do tej sceny skomponowany utwór Liz On Top Of The World autorstwa Dario Marianelliego. Elizabeth wyjeżdża z Longbourn, by w kulminacyjnym momencie fabuły stanąc na „Wichrowym Wzgórzu”, co, stanowiąc kolejne nawiązanie do twórczości sióstr Brontë, podkreśla odejście od klasycznych form dotychczasowych adaptacji powieści Jane Austen.

Analizując historie stworzone przez pisarkę, można zauważyć, że w kluczowych momentach bohaterowie często są otoczeni przez naturę odzwierciedlającą ich aktualny stan emocjonalny. Koncepcja jedności człowieka z natura była popularna wśród przedstawicieli ówczesnego angielskiego romantyzmu. Skorzystali z niej także twórcy adaptacji, przedstawiając charakter i uczucia bohaterów za pośrednictwem przyrody. Jedną z najbardziej typowych scen w tej konwencji sa pierwsze oświadczyny pana Darcy'ego podczas ulewy w parkowym amfiteatrze. W powieściach Austen sceny oświadczyn stanowią punkt zwrotny w życiu bohaterek i niosą ze sobą ogromny ładunek emocjonalny. Założenia autorki zostały trafnie przez twórców rozpoznane i odzwierciedlone w adaptacji filmowej. Podczas ożywionej i emocjonalnej rozmowy Elizabeth i Fitzwilliam wykrzykują skrywane dotąd sądy i opinie o sobie nawzajem. Pomimo deklarowanej niechęci i wewnętrznego gniewu bohaterów, wykonywane przez nich gesty i prezentowana postawa ciała sugerują namiętność i pożądanie. Taka interpretację może potwierdzić fakt, że scena finalnie kończy się nagłym zbliżeniem bohaterów - sugerującym następstwo pocałunku. W celu podkreślenia wyjątkowości i dynamiczności prezentowanego ujęcia, autorzy zdecydowali się także na przedstawienie go w deszczowej, burzliwej scenerii, wśród zieleni na deskach podniszczonego amfiteatru z klasycznymi kolumnami. Niełatwo byłoby zwizualizować tę sytuację w sposób bardziej ostentacyjnie romantyczny.

Druga scena oświadczyn ma zupełnie inny charakter. W porównaniu do sceny zaproponowanej w serialu z 1995 roku - gdzie pan Darcy spaceruje z Elizabeth po polnej drodze w pełnym słońcu, nieśmiało zerkając na wybrankę - interpretacja zaproponowana przez Wrighta raz jeszcze wydaje się o wiele bliższa estetyce gotyckiej. Elizabeth, w narzuconym na nocną koszulę płaszczu, z włosami związanymi w luźny warkocz, spotyka na spowitej poranną mgłą łące równie niekompletnie ubranego Darcy'ego. Przypisane im stroje sprawiaja, że wykorzystana w ujęciu paleta barw jest zgaszona. Scena odbywa się na wzgórzu tuż przed świtem. Lizzy w oddali widzi postać ukochanego, kroczącego ku niej w promieniach powoli wschodzącego słońca. Wokół unosi się poranna mgła. Wyznanie uczuć przez bohaterów jest pełne napięcia. Scena co prawda odbywa się bez konwencjonalnego zakończenia w postaci czułego pocałunku, jednakże w momencie zbliżenia bohaterów 
promienie słońca oświetlają ich postaci, symbolizując szczęśliwe zakończenie w stylu amerykańskiego happy ever after.

\section{Jaki dom, taki właściciel}

Wzniosłego tonu przedstawianej historii nadają nie tylko mgliste krajobrazy, ale także domy bohaterów - co było już częściowo opisane przy analizie pierwszych scen filmu prezentujaccych Longbourn. Obecność elementów wiejskiego życia i prac gospodarskich lub ubłocony knur przeganiany przez pana Benneta w sieni domu, świadczą nie tylko o sytuacji finansowej rodziny, ale także odczarowuja przeestetyzowaną sztuczną przestrzeń wykorzystywaną we wcześniejszych adaptacjach ${ }^{14}$. Wygląd domów w produkcji jasno komunikuje nie tylko pozycję finansowa, ale także charakter i cechy osobowości jego mieszkańców. Ukazany w filmie Basildon Park w hrabstwie Berkshire (odtwarzający Netherfield Park) to okazałe domostwo o nieco surowym klasycznym wnętrzu, które idealnie nadawało się do roli wynajętego lokum rodziny Bingleyów, w którym mieszkańcy pomimo udogodnień czuja się obco i nieswojo. Interesujaccym jest, że zarówno w przypadku Basildon Park, jak i Groombridge Place, scenarzyści zdecydowali się zrezygnować z oryginalnego wystroju dworów do tego stopnia, że nawet ściany zostały przysłonięte specjalnie stworzonymi makietami, przez które pomieszczenia wydają się mniejsze. W założeniach autorów neogreckie i modne jak na przełom XVIII i XIX wieku umeblowanie Netherfield miało nie tylko świadczyć o zamożności jego lokatorów, ale także - a może przede wszystkim - stanowić kontrast do podniszczonego domu Bennetów ${ }^{15}$. Basildon Park z zewnątrz prezentuje się widzowi jako kwintesencja dobrego smaku - klasyczna, symetryczna bryła na tle malowniczego krajobrazu. Wnętrze również utrzymane jest w stylu klasycystycznym, co sprawia, że przestrzeń staje się dystyngowana i zarazem „pozbawiona emocji” - zupełnie jak przedstawiona zamieszkujacca ją angielska arystokracja. Z drugiej strony finezyjne meble Netherfield Park przypominaja ryciny Thomasa Chippendale'a i jego czerpiące $\mathrm{z}$ różnych stylów projekty. Wnętrze może więc nawiązywać nie tylko do osobowości pana Bingleya, ale także do wzoru ówczesnego brytyjskiego arystokraty, który przy hołdowaniu tradycji, równocześnie chce poznawać dalekowschodnie kultury i być może łamać konwenanse społeczne, żeniąc się z damą niższego pochodzenia ${ }^{16}$.

\footnotetext{
${ }^{14}$ Tamże, s. 407.

${ }^{15} \mathrm{Na}$ podstawie wywiadu z Joe Wrightem.

${ }^{16}$ P. Skrodzka, dz. cyt.
} 
Jedną z ważniejszych scen w filmie jest scena balu w Netherfield Park. Widz ogląda wtedy pałac z zupełnie nowej perspektywy - jako miejsce spotkania arystokracji i mniej zamożnej szlachty. Pomimo różnic majątkowych i społecznych, kobiety mają na sobie modne wówczas białe suknie w stylu empire - co dowodzi ich towarzyskiego obycia. Jedynymi gośćmi odstępującymi od normy sa państwo Bennetowie, co prawdopodobnie stanowi intencjonalne działanie reżysera, chcącego kolejny raz podkreślić różnicę między rodzina Elizabeth a rodziną Bingleyów i panem Darcym.

Podobne wrażenie może odnieść odbiorca, oglądając w dalszej części filmu posiadłość Pemberley podczas podróży Lizzy z wujostwem. Do jego inscenizacji autorzy wykorzystali dwa miejsca: Wilton House w Wiltshire (do zdjęć wnętrz) oraz najczęściej odwiedzany przez turystów Pałac Chatsworth w Derbyshire (jako budynek z zewnątrz). Dokonując takiego wybo$\mathrm{ru}$, autorzy prawdopodobnie sugerowali się wspomnieniami samej autorki powieści, która mieszkając w pobliżu posiadłości Chatsworth, przyznaje, że uczyniła ja pierwowzorem dla przyszłego Pemberley ${ }^{17}$. Podczas pierwszego zwiedzania pałacu autorzy, szukając miejsca, w którym filmowa Elizabeth mogłaby dostrzec portret pana Darcy'ego, przypadkowo zauważyli galerię rzeźb - postanowili więc ją wykorzystać i stworzyć specjalne popiersie pana domu, na które podczas oglądania innych dzieł przypadkowo natknie się Lizzy $^{18}$. Poprzez wykorzystanie tego zabiegu scena zyskała dodatkowo wcześniej nieplanowana - aurę intymności poprzez możliwość bardziej bezpośredniego, bliższego, „romantycznego” kontaktu bohaterki z podobizna pana Darcy'ego.

Ostatnią posiadłością ukazaną w filmowej adaptacji jest Burghley House przedstawiona jako pałac Rosings ${ }^{19}$. Wytworna rezydencja o przytłaczającym, ciemnym wnętrzu wybudowana za czasów Elżbiety I, idealnie nadawała się na miejsce zamieszkania Lady Catherine - kobiety dumnej, wyniosłej i apodyktycznej. Jest jednak w filmie jeden element, wyraźnie zaprzeczajacy tendencji autorów filmu do odzwierciedlania charakteru mieszkańców w wyglądzie ich domostwa. Podczas sceny przywitania Elizabeth i państwa Collins, Lady Catherine wraz z córką znajdują się w pomieszczeniu, którego ściany ozdobione są malowidłami przestawiającymi nagie postacie w stylu rubensowskim. Malowidła umieszczone na ścianach można interpretować jako ironiczny kontrast z moralnym purytanizmem

${ }^{17}$ M. Szutka, Pałac możliwości Jane Austen. Rozmowa z prof. dr hab. Ewą Borkowska, kierownikiem Zakładu Kultury i Literatury Brytyjskiej w Instytucie Kultur i Literatur Anglojęzycznych Uniwersytetu Ślaskiego, z okazji 200. rocznicy śmierci Jane Austen, <www. gazeta.us.edu.pl/node/420273> [dostęp: 21.05.2019].

${ }^{18} \mathrm{Na}$ podstawie wywiadu z Joe Wrightem.

${ }_{19}$ Tamże. 
Lady. Z drugiej strony, przedstawione na nich postacie i sceny ukazuja to, co „wyparte” z życia mieszkanek tego domu, utajona zmysłowość, której sobie wzbraniaja, a o której zewsząd im się przypomina.

\section{Filmowa adaptacja Wrighta odejściem od nurtu kina dziedzictwa}

Powyżej opisany mroczny i dynamiczny charakter wielu scen w adaptacji sprawia, że odbiorca, wychodząc ze znanej mu konwencji, pozornie ma możliwość interpretowania przedstawionej historii poza schematem komedii romantycznej. Film w reżyserii Wrighta wyraźnie eksponuje istotny kontekst społeczny wypowiedziany między wierszami w powieści Austen. Dla młodych bohaterek wybór męża to nie tylko zabawa w swaty i szukanie miłości - to dokonanie transakcji życiowej, dzięki której zapewnia sobie i swojej rodzinie bezpieczną pozycję i środki utrzymania ${ }^{20}$. Zależność od zasady majoratu została dobrze uchwycona przez reżysera w scenach rozmowy Elizabeth z przyjaciółką Charlotte Lucas lub oświadczyn pana Collinsa (która, choć odnosiła się do ówczesnego poważnego problemu społecznego i pozycji kobiet, była przedstawiona w przewrotny, humorystyczny sposób). Obdrapane ściany i biedne wnętrza domu rodziny Bennetów podkreślając wagę sytuacji, nieco oddalają widza od wizji „pięknej bajki” z nurtu heritage films i koncentrują jego uwagę na realnym zagrożeniu bohaterek. Interpretując film stworzony przez Wrighta z tej perspektywy, można przyjać, że jego scenografia, przestrzeń i stroje aktorów podkreślają przypisywane reżyserowi odejście od klasycznego stylu adaptacji powieści Jane Austen w nurcie heritage films.

\section{Romantyzm w Dumie i uprzedzeniu Wrighta}

Odejście od estetyki kina dziedzictwa nie oznacza jednak odejścia od romantycznych idei. Duma i uprzedzenie Wrighta koncentruje się na widocznym w powieści Austen dążeniu pisarki do zbadania natury romantycznego ja (romantic self ${ }^{21}$ ) oraz możliwości kobiet i mężczyzn w osiągnięciu

${ }^{20}$ H. Jaxa-Rożen, Kobiety i pieniqdze $w$ twórczości eseistycznej Virginii Woolf $i$ powieściach Jane Austen, „Colloquia Anthropologica et Communicativa” 2010, t. 2, [2] Monety, banknoty $i$ inne środki wymiany, s. 103-104.

${ }^{21}$ S. Ailwod, "What are men to rocks and mountains?" Romanticism in Joe Wright's Pride \& Prejudice, <http://www.jasna.org/persuasions/on-line/vol27no2/ailwood.htm?\#1> [dostęp: 13.01.2019]. 
samorealizacji w opresyjnym patriarchalnym porządku społeczno-gospodarczym. Film eksponuje ten aspekt powieści w reprezentacji postaci Elizabeth Bennet i pana Darcy'ego - podkreślając ich romantyczne cechy osobowości i znaczenie pełnionych funkcji społecznych. Wright wykorzystuje także możliwości filmu, by poprzez wizualizację postaci Elizabeth (w zestawieniu z krajobrazem i sceneria) wyeksponować obecny w dziele Austen konflikt między indywidualnym pożądaniem a porządkiem społecznym w kategoriach romantyzmu. Związek Jane Austen z romantyzmem - pod względem traktowania elementów romantycznej ideologii w jej powieściach - jest kwestią stanowiąca wyzwanie dla badaczy dorobku pisarki. Do niedawna twórczość Austen czytano głównie w oderwaniu od dzieł współczesnych jej romantyków, a same powieści interpretowano raczej jako krytykę lub odrzucanie elementów ideologii romantycznej. Wyniki ostatnich badań wskazały jednak na wcześniej niedostrzegane powiązania między twórczością pisarki a ideami romantyzmu ${ }^{22}$. W Dumie $i$ uprzedzeniu samotność i odizolowanie społeczne wpisane w osobowość głównych bohaterów, nawiązuje do tradycyjnej koncepcji romantycznego rozwoju jednostki. W powieści autorka wyeksponowała także kwestie wpływu różnicy płci na dążenie jednostek do samorealizacji - utożsamianej z koncentracją na indywidualnych pragnieniach.

Stosunek Austen do tradycyjnej koncepcji romantycznej tożsamości i jej złożoności płciowych jest centralną narracją Dumy i uprzedzenia Wrighta. Film koncentruje się na wzajemnej walce Elizabeth i Darcy'ego o indywidualizm w ustalonym porządku społecznym. Podróże bohaterów, poprzez wykorzystanie dramatycznych krajobrazów, sa przedstawione jako walka dwóch romantycznych bohaterów o osiagnięcie samorealizacji niezależnej od świata, w którym żyja.

Pierwsza część Dumy i uprzedzenia Wrighta ustanawia Elizabeth i Darcy'ego jako postaci romantyczne, eksponujac ich indywidualną izolację w niestałej rzeczywistości społecznej. W przypadku panny Bennet świadczą o tym jej liczne przedstawienia na tle przyrody. Na poczatku filmu bohaterka samotnie spaceruje wśród wiejskich krajobrazów, czytając książkę (co może także świadczyć o jej pragnieniu samowystarczalności). Pozycja Elizabeth jako postaci romantycznej jest szczególnie podkreślona podczas jej spaceru z Longbourn do Netherfield. Wright celowo używa odległego ujęcia kamery, aby przedstawić pannę Bennet na tle białego nieba: ona i samotne drzewo sa jedynymi postaciami w nieco mrocznym, lecz idyllicznie wiejskim krajobrazie. Scena przedstawiająca przybycie bohaterki do posiadłości państwa Bingley jeszcze bardziej podkreśla jej związek z naturą i światem przyrody.

${ }^{22}$ Por. A. Mellor, Romanticism and Gender, New York 1993. 
Bardzo ozdobne i formalne wnętrze sali Netherfield jest wizualnym przeciwieństwem natury znajdującej się na zewnątrz. Postać Elizabeth - z rozwianymi, rozpuszczonymi włosami, zabłoconym rąbkiem sukienki oraz brudnymi butami - wyraźnie nie pasuje nie tylko do otoczenia, ale także do innych obecnych w pomieszczeniu postaci symbolizujących określona przestrzeń społeczna. Komentarz panny Bingley, że bohaterka „wyglądała zupełnie średniowiecznie" (She looked positively medieval), podkreśla nieprzystosowanie Elizabeth do ówczesnych form i praktyk społecznych. Indywidualizm Elizabeth przejawia się nie tylko w jej powiązaniach ze światem natury, ale także w scenach wizualnie eksponujących jej społeczne wyobcowanie. Po zakończeniu rozmowy z panem Darcym podczas balu w Maryton, bohaterka idzie samotnie przez środek sali, kierując się ku drzwiom wyjśsiowym. Kamera skupiająca się wyłącznie na Elizabeth zostawia pozostałe postaci w kadrze poza polem ostrości. Wright używa tego wizualnego zabiegu także podczas balu w Netherfield. Długie ujęcia kamery koncentrujące się na różnych postaciach, podkreślające wizualną perspektywę Elizabeth, przedstawiaja ja jako „zewnętrznego obserwatora” życia społecznego.

W pierwszej części Dumy i uprzedzenia Wrighta także pan Darcy - ze względu na nieudane wystapienie podczas balu - jawi się jako postać wyobcowana społecznie. Kiedy bohater wraz z państwem Bingley przybywa na bal w Meryton, muzyka i tańce natychmiast się zatrzymuja, a tłum obecnych odwraca się, by spojrzeć na nowoprzybyłych. Istotne sa tu także techniczne zabiegi wizualne. Kamera przemieszcza się na drugi koniec sali, pokazując bohaterów przechodzących wśród obserwującego ich tłumu. Scena wyraźnie dramatyzuje reakcję społeczności Meryton na przybycie nieznajomych - co można interpretować jako celowe podkreślenie przez reżysera wątku, wyeksponowanego też w powieści Austen, ówczesnych oczekiwań społecznych dotyczących małżeństwa. Sposób stopniowego wprowadzania postaci Darcy'ego przez Wrighta - wyłącznie przez pryzmat jego relacji z panną Bennet - zauważalnie koresponduje z sugestia pisarki o „utowarowieniu mężczyzn” w XIX wieku w aspekcie matrymonialnym. Fakt, że widz ma możliwość poznania bohatera wyłącznie z perspektywy Elizabeth, może dodatkowo świadczyć o uprzywilejowaniu przez reżysera nie tylko perspektywy wizualnej, ale także podmiotowości bohaterki.

W wersji filmowej taniec głównych bohaterów podczas balu w Netherfield również można interpretować jako egzemplifikację ich wyobcowania społecznego i poczucia indywidualności. W kulminacyjnym momencie tańca bohaterowie (prowadząc ożywioną rozmowę o pułkowniku Wickhamie) gwałtownie zatrzymują się, stając naprzeciw siebie na środku sali balowej. Ostrość kamery jest ustawiona wyłącznie na nich, a pozostałe tańczące pary znikają z kadru. Scena wizualizująca społeczne odizolowanie bohaterów, tym 
samym jednocześnie wskazuje łączące ich podobieństwa. Fakt, że po chwili rozmowy para wznawia taniec może być dowodem, że pomimo pragnienia indywidualizmu bohaterowie są uwikłani w silniejsze zależności towarzyskie.

Następne spotkanie Elizabeth i Darcy'ego w Rosings eksponuje pozycję obojga bohaterów i związane z tym trudności. Wytworne wnętrze pałacu oraz postać Lady Catherine symbolizują oczekiwania społeczne względem małżeństwa, zgodnie z obowiąującym patriarchalnym porządkiem. W pierwszej scenie przedstawiającej pana Darcy'ego w Rosings mężczyzna stoi obok ptaka zamkniętego w klatce. Wykorzystanie tego rekwizytu przez Wrighta można interpretować jako podkreślenie sytuacji bohatera - „zamkniętego” w oczekiwaniach związanych z jego pozycja.

Część akcji rozgrywająca się w pałacu Rosings kontynuuje wcześniejsze wykorzystanie kontrastu wnętrza i otoczenia w filmie, podkreślając, że nie tylko Elizabeth, ale także Darcy znajdują źródło samorealizacji w świecie przyrody. W przeciwieństwie do sekwencji otwierających i kończących film, większość scen w Rosings i Hunsford zostało nakręconych w pomieszczeniach, a akcent przesunięto na społeczne relacje bohaterów. Jedyny wyjatek stanowi scena, kiedy bohaterka wykorzystuje świat natury jako środek ucieczki i emocjonalnego uwolnienia po rozmowie z panem Darcym o jego roli w rozdzieleniu pana Bingleya i Jane Bennet. Elizabeth biegnie sama w deszczu - co stanowi obraz siły towarzyszacych jej uczuć. Ta scena plenerowa kończąca się pierwszymi oświadczynami Darcy'ego, wskazuje ponadto, że również on traktuje przyrodę jako sposób ucieczki i zaznania wolności od opresyjnych wnętrz Rosings.

Poza wcześniej opisanymi kontrastami między przestrzeniami wewnętrznymi a zewnętrznym otoczeniem, film Wrighta celowo wykorzystuje różnice między stylami ogrodów i typami krajobrazu. Pierwsza scena oświadczyn została nakręcona w świątyni Apollina w ogrodzie w Stourhead obecnie uważanym za arcydzieło XVIII-wiecznego angielskiego klasycyzmu. Plan ogrodu stanowi kwintesencję zasad estetycznych usilnie obalanych przez przedstawicieli romantyzmu, preferujacych dziksze, bardziej naturalne i surowe krajobrazy. Interesujące jest, że nieudana propozycja małżeństwa Darcy'ego ma zatem miejsce w otoczeniu symbolizującym porządek estetyczny, który obie postacie - sądząc po ich zachowaniu i sposobie kreacji w filmie - uważałyby za uciążliwy.

Niezgodność między bohaterami a wnętrzem i terenem w Rosings jest szczególnie uderzająca w porównaniu z ich późniejszym spotkaniem w Derbyshire. Szerokie wykorzystanie krajobrazu przez Wrighta w tej części filmu podkreśla aspekt powieści Austen, który często pomijany jest w analizach. Decyzja pisarki o ulokowaniu Pemberley w Derbyshire była podyktowana nie tylko okazałością rezydencji, ale prawdopodobnie także malowniczością 
przestrzeni, która pomaga ukonstytuować postać Darcy'ego jako bohatera romantycznego ${ }^{23}$. Wright używa długiego ujęcia z kamery, aby przedstawić Elizabeth stojąca na klifie - sytuując ją jako część tego dzikiego i surowego krajobrazu. Następnie film ukazuje zbliżenie twarzy bohaterki, aby widz mógł zobaczyć jej reakcję emocjonalną. Kolejne sceny przestawiające Elizabeth siedzącą na pękatych, porośniętych mchem korzeniach, do złudzenia przypominaja najbardziej typowe malarskie przedstawienia romantycznego pejzażu. Dodatkowo, w momencie zbliżania się bohaterki do Pemberley, w kadrze widać przebiegającego jelenia, którego obecność można odczytywać jako ucieleśnienie romantycznych idei dzikości i wolności natury.

Podobnie jak w powieści, wizyta Elizabeth w posiadłości Darcy’ego ma w filmie kluczowe znaczenie. W tej części filmu Wright przedstawia proces zmiany poglądów Elizabeth na temat właściciela Pemberley za pomocą takich środków, jak uprzywilejowanie jej perspektywy wizualnej i skupienie się na oczach bohaterki. W kolejnej scenie kamera podąża zgodnie z perspektywą bohaterki wzdłuż fresków Pemberley, które kontrastują z freskami w Rosings, przedstawiając mężczyzn i kobiety w pasterskich, w pastoralnych, silnie wyidealizowanych pozach. Po tej scenie kamera ponownie koncentruje się na perspektywie Elizabeth, która spogląda przez okno na ogrody Pemberley. Zmiana ostrości, a tym samym zmiana szkła półprzezroczystego w przezroczyste, odzwierciedla nowa ,jasność” jej rozumienia charakteru pana Darcy’ego. Posiadłość Pemberley w krajobrazie Derbyshire jest przedstawiona $\mathrm{w}$ filmie jako romantyczna oaza w wyobcowanym świecie społecznym, która może zapewnić tym dwóm osobom przestrzeń do współistnienia, zachowując jednocześnie ich indywidualną integralność.

Drugie oświadczyny Darcy'ego nieprzypadkowo mają miejsce tam, gdzie zaczyna się film: na wsi wokół Longbourn o świcie. Ta propozycja małżeństwa, a zwłaszcza stwierdzenie, że Elizabeth oczarowała go zarówno wygladem, jak i charakterem, potwierdza kreację postaci na wzór bohatera romantycznego - człowieka kierowanego namiętnym uczuciem, które pozwala mu przezwyciężyć zasady porządku społecznego. Czas, miejsce spotkania oraz niekompletne ubranie bohaterów potwierdza fakt, że ich związek stanowi oderwanie od obowiązujacych form i praktyk społecznych.

\section{Podsumowanie}

W warstwie wizualnej filmowa adaptacja zaproponowana przez Wrighta pomimo odejścia od konwencji kina dziedzictwa, jest w podobnym stopniu

${ }^{23} \mathrm{Na}$ podstawie wywiadu z Joe Wrightem. 
przeestetyzowana, co wcześniejsze adaptacje, lecz w inny sposób. Podążanie w kierunku estetyki brzydoty pełnym błota, brudu, mroku, działania gwałtownych żywiołów i „realizmu” wydaje się być konwencją podobną do tej, jaką w latach dziewięćdziesiątych była konwencja heritage films. W filmowych ujęciach wszystkie drogi są błotniste, pola zamglone, a niebo - o ile właśnie nie pada deszcz - jest pochmurne lub wręcz złowrogie. Kadry sa tu na wskroś malarskie - w sytuacjach spotkań towarzyskich bohaterowie ustawiają się tak, jakby wręcz pozowali do zbiorowych portretów, a sceny z codziennego życia na wsi ze względu na ich dynamikę i dopasowana pod każdym względem kolorystykę wyglądają jak klasyczne obrazy scen rodzajowych. Film wciąż ma na celu wywołanie u widza poczucia nostalgii i przyjemności wynikającej z kontaktu z kadrami przedstawiającymi „piękne, dawne czasy romantycznych miłości”, ale czepek z kokardą zostaje zamieniony na ubłocony rąbek bawełnianej sukienki ${ }^{24}$.

Zastosowanie tych zabiegów estetycznych ma jednak swoje uzasadnienie. Duma i uprzedzenie Wrighta to jedna z najbardziej romantycznych interpretacji powieści Austen. Reżyser wykorzystał wizualne możliwości filmu, by przedstawić Elizabeth i Darcy'ego jako bohaterów romantycznych dążących do samorealizacji. Chociaż wykorzystanie krajobrazu i natury przez reżysera znacznie wykracza poza fabułę powieści Austen, to podstawa jego interpretacji postaci - pod względem ich buntowniczej indywidualności, izolacji społecznej i charakteru relacji - wydaje się najbliższa fabule i przesłaniu oryginalnej powieści.

\title{
BIBLIOGRAFIA
}

\author{
OPRACOWANIA
}

Bloom H., Jak czytać i po co, przeł. A. Kunicka, Warszawa 2019.

Bloom H., Zachodni kanon, przeł. B. Baran i M. Szczubiałka, Warszawa 2019.

Jaxa-Rożen H., Kobiety i pieniadze w twórczości eseistycznej Virginii Woolf i powieściach Jane Austen, „Colloquia Anthropologica et Communicativa” 2010, t. 2, [2] Monety, banknoty $i$ inne środki wymiany.

Mellor A., Romanticism and Gender, New York 1993.

Niemczyńska A., Kino kobiet? Pomiędzy romantyzmem a feminizmem - adaptacje powieści Jane Austen lat dziewięćdziesiatych, Kraków 2011.

Olszowska M., Duma i uprzedzenie Jane Austen: historia Lizzy, [w:] Od Jane Austen do Iana McEwana. Adaptacje literatury brytyjskiej, red. A. Helman, B. Kazana, Warszawa 2011.

${ }^{24}$ A. Urbanik-Kopeć, dz. cyt., s. 405. 
Scholtz A.M., From Fidelity to History: Film Adaptations as Cultural Events in the Twentieth Century, New York 2013.

Stillinger J., Abrams M.H., The Romantic Period, [w:] The Norton Anthology of English Literature, vol. 2, red. M.H. Abrams, New York, London 1995.

Urbanik-Kopeć A., Czepek z kokarda i ubłocona sukienka-estetyczne uniwersum filmowych adaptacji powieści Jane Austen, [w]: 50 twarzy popkultury, red. K. Olkusz, Kraków 2017.

Włodek P., Domniemany konserwatyzm heritage film, „Ekrany” 2012, nr 5/6.

Wróblewska A., Wspótczesne adaptacje powieści Jane Austen. „Lizzie Bennet Daries” jako narracja transmedialna, „Biblioteka Postscriptum Polonistycznego” 2015, nr 5.

FILMOGRAFIA

Duma i uprzedzenie, reż. S. Langton, scen. A. Davies, BBC 1995.

Duma i uprzedzenie, reż. J. Wright, [DVD] Polska, Filmostrada 2005.

\section{ŹRÓDŁA INTERNETOWE}

Ailwod S., "What are men to rocks and mountains?" Romanticism in Joe Wright's Pride \& Prejudice, <http://www.jasna.org/persuasions/on-line/vol27no2/ailwood.htm?\#1> [dostęp: 13.01.2019].

BBC America, Keira Knightley Is Not Too Pretty For Movies - The Graham Norton Show on BBC America, YouTube.com 2014, <https://www.youtube.com/watch?v=FypcyrvpTp4> [dostęp: 20.05.2019].

Kempna-Pieniążek M., Realizm, ale jaki?, <http://artpapier.com/index.php?page=artykul\&wydanie=10\&artykul=216> [dostęp: 20.05.2019].

Kowalska O., Wspominajac wielkich: Niesmiertelna Jane Austen, <http://niestatystyczny.pl/2017/01/14/wspominajac-wielkich-niesmiertelna-jane-austen/> [dostęp:16.01.2019].

Pride and Prejudice US Alternative Ending, <https://www.youtube.com/watch?v=Zg7YhN-I2M0> [dostęp: 24.05.2019].

Skrodzka P., Kulturowe uwarunkowania wyboru posiadtości wykorzystanych na planie Dumy i uprzedzenia, <www.janeausten.pl/317,groombridge-place-oraz-basildon-park-jako-przykład-wykorzystania-3> [dostęp: 20.05.2019].

Szutka M., Pałac możliwości Jane Austen. Rozmowa z prof. dr hab. Ewą Borkowska, kierownikiem Zakładu Kultury i Literatury Brytyjskiej w Instytucie Kultur i Literatur Anglojęzycznych Uniwersytetu Śląskiego, z okazji 200. rocznicy śmierci Jane Austen, <www.gazeta.us.edu.pl/node/420273> [dostęp: 21.05.2019]. 



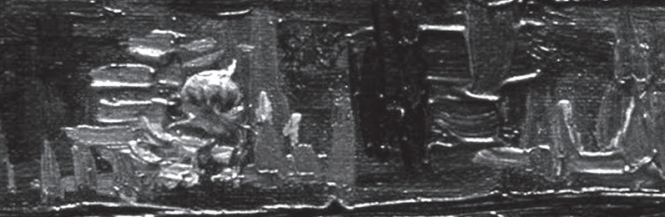

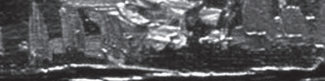

(1)

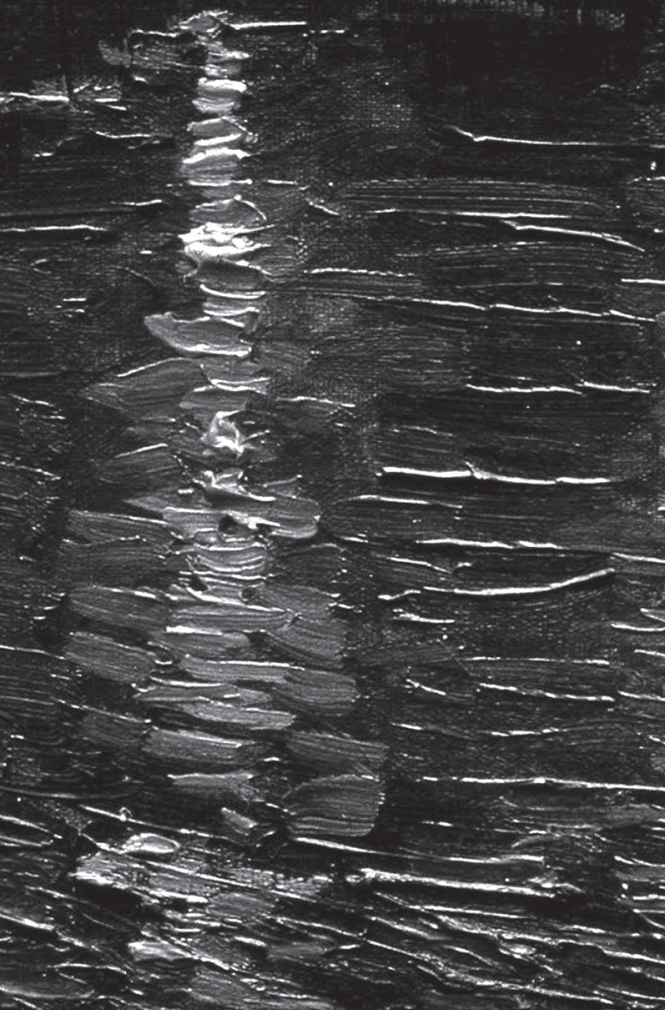

sects.

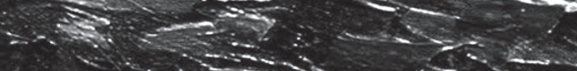

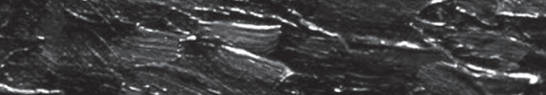

$\because \quad-2,-2$

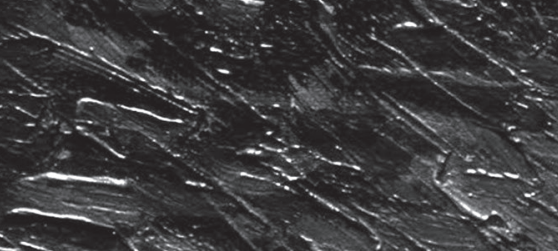

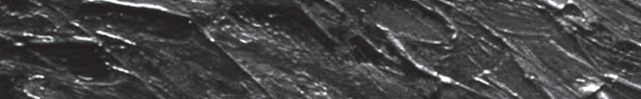
an $x^{2}$, S.

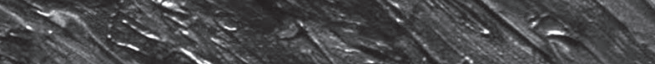

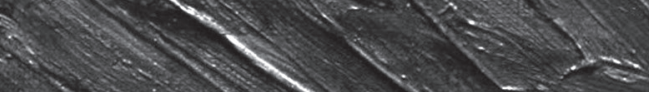
$\therefore$. 3 -

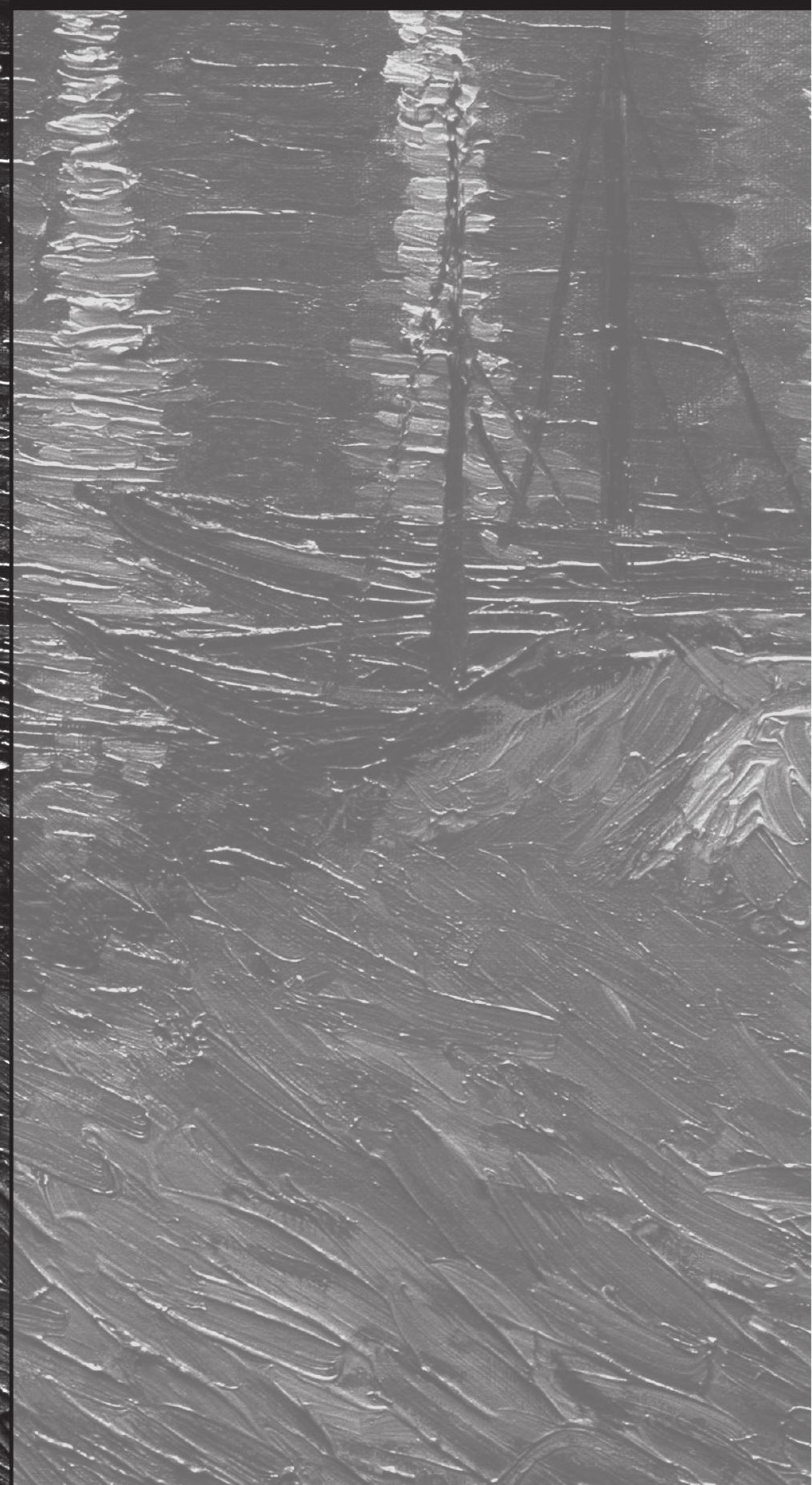


